\title{
Pemberdayaan aset pekarangan masyarakat Desa Alue Pinenung Kota Langsa di masa pandemi Covid-19
}

\author{
Soleka ${ }^{1}$, Rizky Andana Pohan ${ }^{2}$
}

1,2 Insitut Agama Islam Negeri Langsa

email: solekasoleka299@gmail.com

First received:

01 January 2021
Revised:

02 February 2021
Final Accepted:

04 April 2021

\begin{abstract}
Abstrak
Pandemi Covid-19 telah banyak merubah pola tatanan kehidupan masyarakat, terutama yang berkaitan dengan aspek ekonomi. Salah satu metode menemukenali aset bersama dengan masyarakat Desa Alue Pineung melalui metode Low Hanging Fruit yaitu pemanfaatan lahan pekarangan rumah menjadi tempat bercocok tanam. Metode pemberdayaan masyarakat yang digunakan bersama masyarakat berbasis Aset Based Community Development (ABCD). Lokasi Pemberdayaan masyarakat di desa Alue Pineung Kota Langsa. Lama pelaksanaan pemberdayaan masyarakat selama 45 hari. Langkah-langkah pelaksanaan kegiatan pemberdayaan antara lain: (1) pemetaan aset bersama masyarkat sehingga didapatkan potensi lahan pekarangan rumah, (2) Gotong royong membersihkan lahan masing-masing, (3) belajar bersama memanfaatkan media internet untuk menentukan tanaman dan pola yaqng cocok untuk di tanam di daerah Langsa, (4) Menentukan tanaman yang tepat yaitu sayuran dan buah-buahan, (5) Menyiapkan lahan pekarangan yang siap untuk di tanam baik melalui polibag maupun membuat bedengan-bedengan, (6) Penanaman sayuran dan buah-buahan, (7) Perawatan tanaman melalui penyiraman, pemupukan dan pembersihan rumput. Pemberdayaan ini menyadarkan masyarakat bahwa pekarangan yang sempit juga dapat menghasilkan sesuatu yang bermanfaat jika dikelola dengan baik.
\end{abstract}

Kata Kunci: Lahan pekarangan, aset, pandemi Covid-19, ABCD

\section{Abstract}

The Covid-19 pandemic has changed many patterns of community life, especially those related to economic aspects. One method of identifying joint assets with the people of Alue Pineung Village is through the Low Hanging Fruit method, namely the use of house yards as a place to grow crops. The community empowerment method used with the community is based on Asset Based Community Development (ABCD). Locations for community empowerment in the village of Alue Pineung, Langsa City. The duration of the implementation of community empowerment is 45 days. The steps for implementing empowerment activities include: (1) mapping of assets with the community so that the potential for home yards can be obtained, (2) mutual cooperation to clear each other's land, (3) learning together to use internet media to determine plants and patterns that are suitable for planted in the 
Langsa area, (4) Determining the right plants, namely vegetables and fruits, (5) Preparing yards that are ready for planting either through polybags or making beds, (6) Planting vegetables and fruits, (7) Plant care through watering, fertilizing and cleaning the grass. This empowerment makes people aware that narrow yards can also produce something useful if managed properly.

Keywords: Yard, assets, the Covid-19 pandemic, ABCD

\section{PENDAHULUAN}

Pandemi Covid-19 telah merubah tatanan dan pola kehidupan masyarakat terutama bidang ekonomi. Pembatasan interaksi sosial mengubah tatanan pola kehidupan masyarkat. Hal ini membuat beberapa masyarakat terkena dampaknya baik secara langsung maupun tidak langsung. Salah satu desa yang terkena dampak tersebut adalah Desa Alue Pineung. Pemanfaatan lahan seperti alih fungsi lahan pertanian menambah daftar permasalahan yang menambah beban ketahanan pangan. Semakin sempitnya luas lahan sawah akan menghambat terjadinya peningkatan kapasitas produksi pangan (Sajogyo, dkk, 1994). Meskipun demikian untuk masyarakat perkotaan, lahan yang terbatas juga dapat dimanfaatkan semaksimal mungkin.

Lahan pekarangan dapat memiliki banyak fungsi multiguna, karena dari lahan yang relatif sempit bisa menghasilkan bahan pangan seperti sayuran, bunga, buahbuahan; bahan tanaman rempah dan obat, bahan kerajinan tangan, serta bahan pangan hewani yang berasal dari unggas, ternak kecil maupun ikan (Ariati, 2017). Salah satu manfaat yang diperoleh dari pengelolaan pekarangan antara lain dapat memenuhi kebutuhan konsumsi dan gizi keluarga, menghemat pengeluaran harian rumah tangga, dan memberikan tambahan pendapatan (Haryati, dkk, 2015). Manfaat tersebut akan dapat diperoleh apabila pekarangan dirancang, direncanakan dan dikelola dengan baik. Salah satu sumber daya yang belum banyak dimanfaatkan oleh masyarakat adalah lahan pekarangan sekitar rumah. Padahal pemanfaatan lahan pekarangan untuk pengembangan pangan rumah tangga adalah merupakan salah satu alternatif untuk mewujudkan kemandirian pangan rumah tangga terlebih di masa pandemi covid-19 seperti sekarang ini. Apabila ini tidak diperhatikan maka akan menimbulkan dampak kerawanan pangan. Kerawanan pangan adalah kondisi tidak tercapainya ketahanan pangan di tingkat wilayah maupun rumah tangga/individu (Amaliyah, 2011). Masalah ketahanan pangan nasional merupakan masalah yang harus ditangani secara bersama. Tidak hanya menunggu bantuan pemerintah, namun harus didukung dengan peran aktif masyarakat untuk memanfaatkan lahan pekarangan keluarga masing-masing.

Oleh karenanya penguatan ketahanan pangan keluarga secara signifikan melalui pemanfaatkan pekarangan. Pekarangan bukan hanya untuk menciptakan keindahan dan kesejukan saja, tetapi lebih daripada itu adalah guna meningkatkan perekonomian keluarga masing-masing. Jenis-jenis tanaman yang bisa ditanam di pekarangan rumah masing-masing adalah jenis sayur-sayuran, buah- buahan, obat-obatan, tanaman hias, dan lain sebagainya yang kesemuanya itu dapat menunjang kebutuhan sehari- hari dan selebihnya bisa dijual (Dwiratna, dkk, 2016). Ketersediaan pangan dalam jumlah yang cukup sepanjang waktu merupakan keniscayaan yang harus diperkuat oleh masyarakat. 
Dengan demikian, peranan lahan pekarangan secara tidak langsung mampu mempengaruhi ekonomi rumah tangga. Sempitnya lahan-lahan pekarangan khususnya di daerah perkotaan tidaklah menjadi hambatan dan halangan untuk suatu kegiatan budidaya (Yusuf, 2018). Sistem pertanian kota dengan ketersediaan lahan yang sempit, dapat dijalankan dengan usaha berbagai perkembangan teknologi yang hemat lahan.

Hal inilah juga yang mendasari pengabdi untuk bersama-sama masyarakat memberdayakan pekarangan rumah maupun lingkungan yang tidak terawat dan dibiarkan terlantar begitu saja. Lahan yang sempit tetapi jika dimanfaatkan secara maksimal juga akan menghasilkan sesuatu yang bermanfaat terutama untuk menunjang aspek ekonomi masyarakat Desa Alue Pineung selama pandemi Covid-19. Berdasarkan analisis kebutuhan (Pohan, dkk, 2020) dan pemetaan aset yang dilakukan bersama warga maka disepakati sebuah program pemberdayaan masyarakat dengan pemanfaatan lahan kosong untuk dikelola sebagai lahan pertanian yang dapat bermanfaat untuk masyarakat.

\section{METODE}

Pelaksanaan pemberdayaan masyarakat dilaksanakan di Desa Alue Pineung Kota Langsa selama 45 hari. Subjek pengabdian merupakan seluruh warga masyarakat yang memiliki potensi pekarangan rumah yang belum termanfaatkan dengan baik. Metode pengabdian yang digunakan berbasis potensi ataupun aset masyarakat yaitu ABCD (Asset Based Community Development (Haines, 2009). Analisis keberhasilan diketahui melalui kegiatan monitoring dan evalaluasi yang meliputi: perubahan yang signifikan, alur sejarah, alur sirkulasi keuangan, pemetaan fisik, serta pemetaan institusi (Salahuddin, 2015).

\section{HASIL DAN PEMBAHASAN}

Program pemberdayaan masyarakat dilaksanakan selama \pm 45 hari terhitung sejak tanggal 1 Desember 2020 sampai 14 Januari 2021. Langkah-langkah pelaksanaan kegiatan pemberdayaan antara lain: (1) pemetaan aset bersama masyarkat sehingga didapatkan potensi lahan pekarangan rumah, (2) Gotong royong membersihkan lahan masingmasing, (3) belajar bersama memanfaatkan media internet untuk menentukan tanaman dan pola yaqng cocok untuk di tanam di daerah Langsa, (4) Menentukan tanaman yang tepat yaitu sayuran dan buah-buahan, (5) Menyiapkan lahan pekarangan yang siap untuk di tanam baik melalui polibag maupun membuat bedengan-bedengan, (6) Penanaman sayuran dan buah-buahan, (7) Perawatan tanaman melalui penyiraman, pemupukan dan pembersihan rumput. Hasil dari pemberdayan ini terlihat bahwa sebelum dan sesudah dilaksnakan masyarkat mulai memahami manfaat pekrangan rumah yang sedikit namun jika dimanfaatkan juga bisa menghasilkan untuk mendukung ketahanan pangan maupun perekonomian masyarakat. Secara siginifikan seluruh masyarakat mulai tersadar dan bersemngat untuk menanami seluruh pekrangan rumah yang selama ini terbengkalai dan tidak dimanfaatkan. Berikut ini gambar alur pelaksanaan pemberdayaan masyarakat yang telah dilaksanakan 


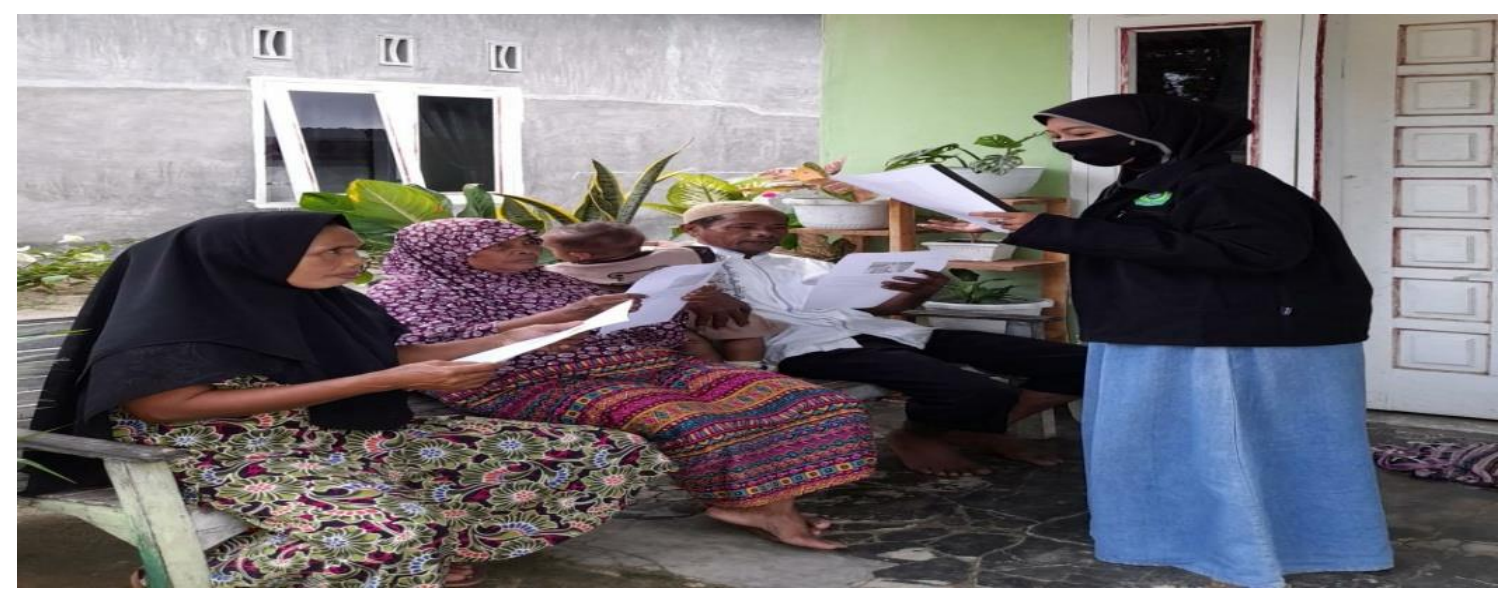

Gambar 1. Pemetaan Aset bersama masyarakat

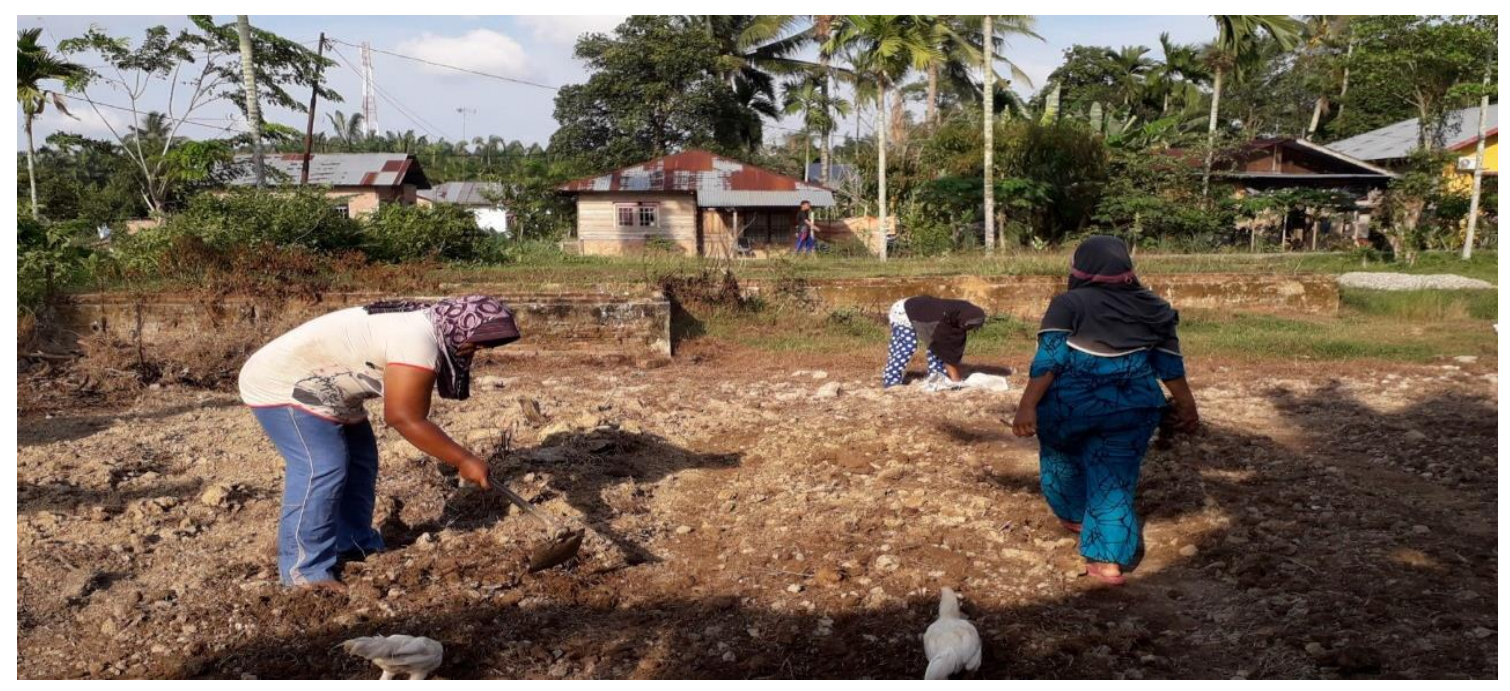

Gambar 2. Gotong Royong membersihkan lahan pekarangan
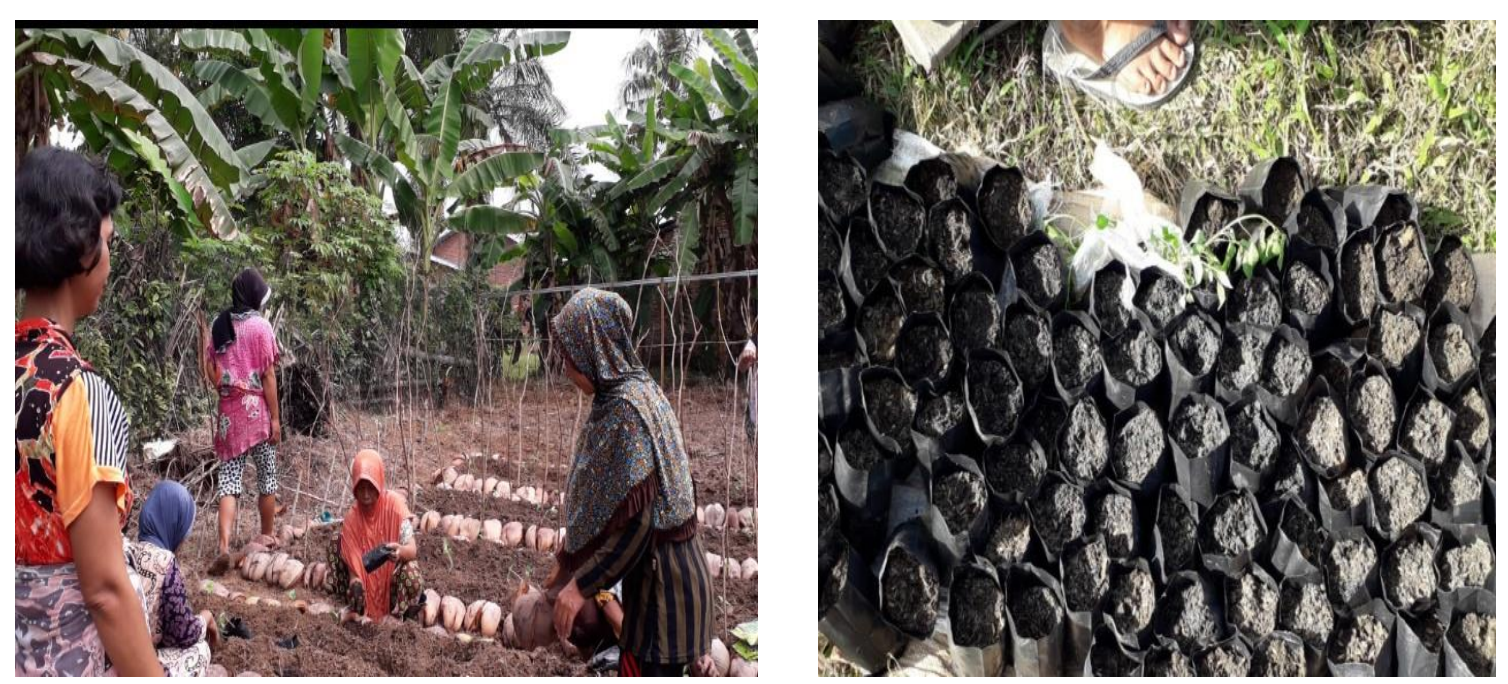

Gambar 3. Penyiapan lahan pekarangan melalui bedengan dan polibag 

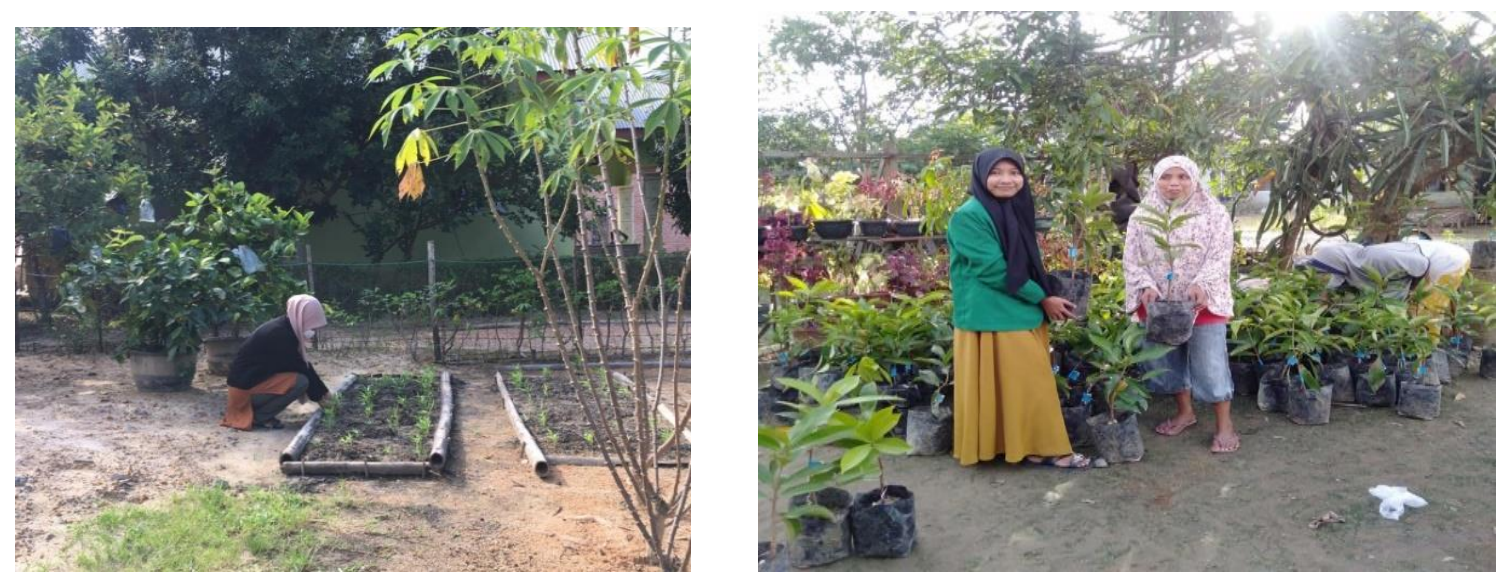

\section{Gambar 4. Penanaman Sayuran dan buah-buahan}

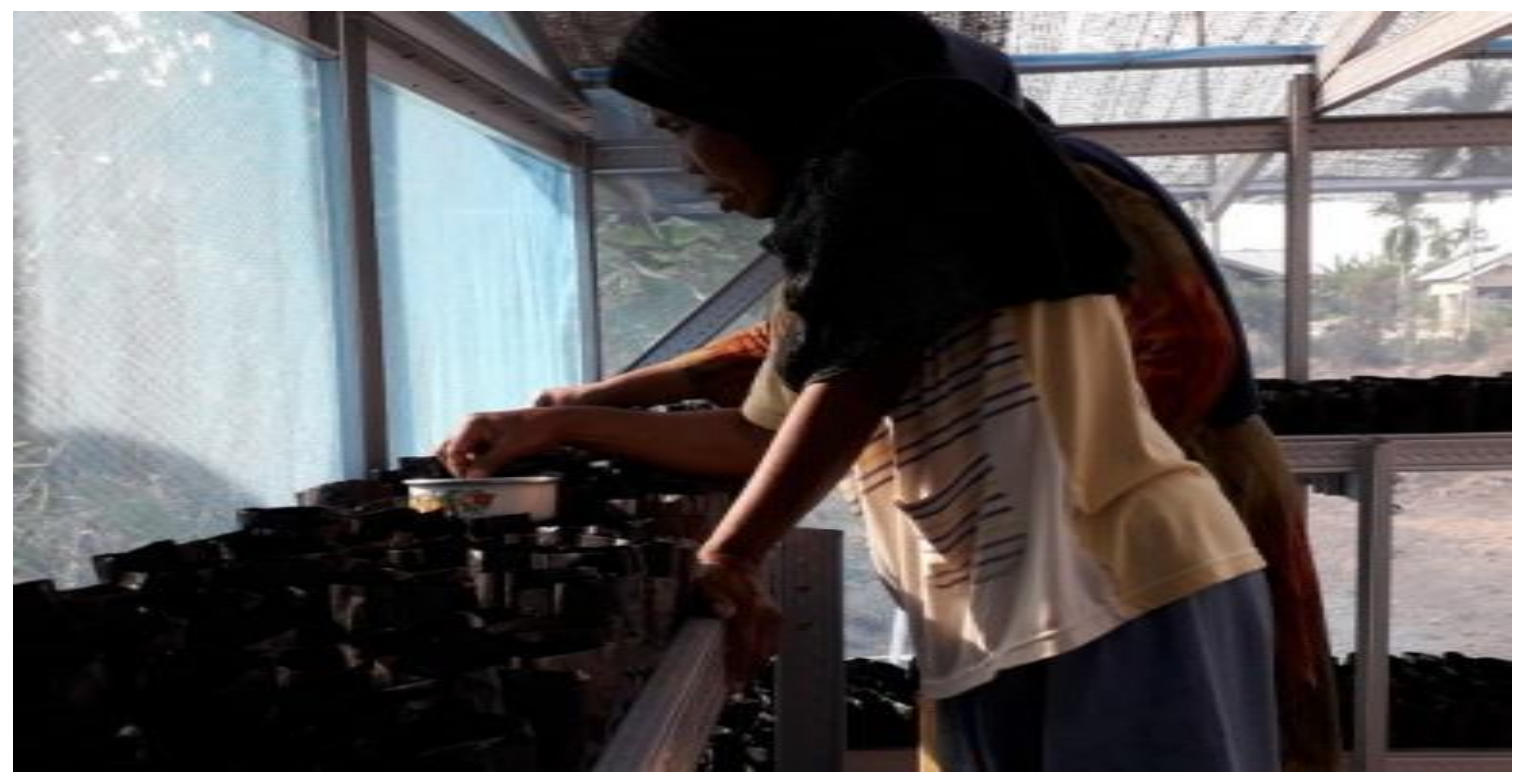

Gambar 5. Perawatan tanaman

Pemanfaatan Lahan Pekarangan di masyarakat melalui penanaman tanaman sayur dan buah-buahan

Bersama masyarkat pengabdi mulai memberdayakan lahan yang kosong di sekitar masyarakat. Setelah dianlisis ternyata ditemukan sebuah lahan yang dimiliki desa yang cukup luas namun selama ini tidak termanfaatkan. Inilah yang kemudian disepakati menjadi aset utama, ditambah lagi dengan aset pekarangan rumah warga masing-masing. Bersama warga kami mengolah lahan yang ada dengan membersihkan rumput, menggemburkan tanah, kemudian mendiskusikan tanaman yang tepat untuk ditanam. Hasilnya disepakati bahwa yang ditanama adalah sayuran dan buah-buahan. Sayauran dengan pertimbangan bahwa akan cepat menghasilkan, sementara buah-buahan untuk dinikmati dalam jangka waktu yang panjang. Kebersamaan pemberdayaan ini kemudian terus berlanjut sampai pada tahap perawatan. Seluruh masyarakat bersinergi untuk memanfaatkan lahan desa, dan secara individu masyarakat juga bersemangat untuk 
mengolah lahan pekarangan masing-masing. Antusiasme dan respon masyarakat sangat baik karena memang pemetaan aset yang dilakukan secara bersama-sama dengan melibatkan banyak pihak, dengan tetap memperhatikan respon dari pihak-pihak terkait baik pertanyaan, sanggahan, masukan dari mereka (Pohan, 2016). Saat ini tanaman sudah tumbuah dan masuk dalam tahap proses perawatan dan tinggal menunggu hasil panen untuk sayuran. Keberhasilan pemberdayaan ini tidak terlepas dari strategi pemberdayaan ABCD yaitu memanfaatkan potensi terdekat terlih dahulu, baru kemudian menemukan aset yang lebih besar untuk tujuan bersama (Mathie, dkk, 2017).

\section{KESIMPULAN}

Program pengabdian masyarakat berbasis $A B C D$ ini terbukti berhasil meningkatkan kesadaran masyarakat untuk memanfaatkan sesuatu hal yang selama ini terbengkalai yaitu lahan pekarangan namun ternyata dapat dimanfaatkan untuk menambah ketahanan pangan dan ekonomi keluarga selama maupun pasca pandemi Covid-19. Program ini berhasil dikarenakan pemetaan aset yang dilakukan secara bersama-sama dengan masyarakat berdasarkan atas potensi-potensi yang paling dekat dimiliki.

\section{UCAPAN TERIMAKASIH}

Kami mengucapkan terimakasih kepada LP2M IAIN Langsa yang telah mendukung program pengabdian ini serta kepada seluruh kelompok ibu-ibu Desa Alue Pineung yang telah berperan aktif dalam pelaksanaan program dan juga semua rekanrekan yang telah membantu kelangsungan program pemberdayan masyarakat.

\section{DAFTAR PUSTAKA}

Amaliyah, H. (2011). Analisis hubungan proporsi pengeluaran dan konsumsi pangan dengan ketahanan pangan rumah tangga petani padi di Kabupaten Klaten.

Ariati, P. E. P. (2017). Produksi beberapa tanaman sayuran dengan sistem vertikultur di lahan pekarangan. Jurnal Agrimeta, 7(13).

Dwiratna, S., Widyasanti, A., \& Rahmah, D. M. (2016). Pemanfaatan lahan pekarangan dengan menerapkan konsep kawasan rumah pangan lestari. Dharmakarya, 5(1).

Haines, A. (2009). Asset-based community development. An introduction to community development, 38, 48 .

Haryati, Y., \& Sukmaya, M. (2015). Peran kebun bibit desa (KBD) dalam pengembangan kawasan rumah pangan lestari.

Mathie, A., Cameron, J., \& Gibson, K. (2017). Asset-based and citizen-led development: Using a diffracted power lens to analyze the possibilities and challenges. Progress in Development Studies, 17(1), 54-66.

Pohan, R. A. (2016). Kontribusi Kepercayaan Diri dan Persepsi Siswa terhadap Kegiatan Merespon dalam Pembelajaran Serta Implikasinya dalam Bimbingan dan Konseling. Jurnal Penelitian Bimbingan dan Konseling, 1(2). 
Pohan, R. A., \& Siregar, M. (2020). Need Assesment of Guidance and Counseling Module to Improve Freshmen Self-Adjustment. Biblio Couns: Jurnal Kajian Konseling dan Pendidikan, 3(3), 113-119.

Sajogyo, G., Roesli, S., Harjadi, S. S., \& Khumaedi, M. (1994). Menuju Gizi Baik yang Merata di Pedesaan dan di Kota.

Salahuddin, N. (2015). Panduan KKN ABCD UIN Sunan Ampel Surabaya Asset Based Community-Driven Development (ABCD).

Yusuf, A. (2018). Optimalisasi Lahan Pekarangan Untuk Mendukung Ketahanan Pangan Dan Ekonomi Keluarga. Jurnal Pengabdian Kepada Masyarakat, 2(2), 104-107. 